\title{
DNA Metiltransferaz-3b ve Metil Bağlayan Bölge Proteini-1'i Hedefleyen Mirna Gen Polimorfizmlerinin Akciğer Kanseri İle İlişkisinin Belirlenmesi \\ ${ }^{1}$ Cansu Özbayer, ${ }^{1}$ İrfan Değirmenci, ${ }^{2}$ Derya Üstüner, ${ }^{3}$ Güntülü Ak, ${ }^{4}$ Faruk Saydam, ${ }^{5}$ Ertuğrul Çolak, ${ }^{1}$ Hasan Veysi Güneş, ${ }^{3}$ Muzaffer Metintaş

\author{
${ }^{1}$ Eskişehir Osmangazi Üniversitesi Tıp Fakültesi Tıbbi Biyoloji Anabilim Dalı, \\ ${ }^{2}$ Eskişehir Osmangazi Üniversitesi Sağllk Hizmetleri Meslek Yüksekokulu, \\ ${ }^{3}$ Eskişehir Osmangazi Üniversitesi Tıp Fakültesi Göğüs Hastalıkları Anabilim Dalı, \\ ${ }^{4}$ Recep Tayyip Erdoğan Üniversitesi Tıp Fakültesi Tıbbi Biyoloji ve Genetik Anabilim Dalı \\ ${ }^{5}$ Eskişehir Osmangazi Üniversitesi Tıp Fakültesi Biyoistatistik Anabilim Dalı, \\ e-posta: c.ozbayer@gmail.com
}

ÖZET: Akciğer kanseri, akciğer dokusundaki hücrelerin kontrolsüz olarak çoğalması ile meydana gelir ve kanser kaynaklı ölümlerin en yaygın nedenidir. En önemli nedenleri uzun süreli sigara dumanı maruziyeti, genetik faktörler, radon gazı ve asbest maruziyetidir. miRNA'lar kendi nükleotid dizilerinin tamamlayıcısı olan hedef mRNA'lara bağlanıp translasyonel baskılama veya mRNA yıkımı ile transkripsiyon sonrası gen ekspresyonunun düzenlenmesini gerçekleştirirler. Çeşitli çalışmalarda malignant tümörlerin gelişimi ve ilerlemesi ile miRNA ekspresyon düzensizliklerinin ilişkili olduğu, miRNA'ların onkogen veya tümör süpresör (baskılayıcı) olarak hareket edebileceği belirtilmiştir. Ayrıca tümör baskılayıcı genlerin downregülasyonu ve $\mathrm{CpG}$ dinükleotidlerindeki promotör hipermetilasyonu tümörogenezis için önemli bir mekanizmadır. Bir diğer epigenetik düzenleme olan miRNA'ların, genlerin promotör bölgelerindeki anormal metilasyon ve histon modifikasyonları gibi epigenetik mekanizmaları düzenleyebileceği bildirilmiştir. Bu amaçla biz de güncel veri tabanları ile DNMT3b ve MBD1'i hedefleyen 2 miRNA genine ait iki SNP belirleyerek bu SNP'lerin akciğer kanseri ile ilişkisini araştırmayı amaçladık. Gereç ve Yöntem: Çalışmamıza 90 sağlıklı kontrol birey ve 90 akciğer kanseri hastası dahil edildi (onay no: 2012/45). EDTA'll tüplere alınan kan örneklerinden DNA izole edildi ve bu DNA'lar Sequenom MassARRAY sistemi ile genotiplendirildi. Hastalarn genetik varyasyon tipleri ve demografik özellikleri uygun istatistiksel yöntemler ile değerlendirildi. Bulgular: DNMT3b'yi hedefleyen miR339 geni rs72631831 varyantı tüm bireyler için atasal GG genotipine, MBD1'i hedefleyen miR15b geni rs146020563 varyantı için tüm bireyler atasal AA genotipine sahip olarak belirlendi. Sonuç: Araştırmamızda rs72631831 ve rs146020563 varyasyonları ile akciğer kanseri arasında ilişki bulunamamıştır ancak araştırmamız DNA metilasyon mekanizmasını hedefleyen miRNA gen varyantlarının da fonksiyonel karakterizasyonunun yapıldığı ilk çalışma olması nedeniyle önemlidir.

ANAHTAR KELIMELER: Akciğer Kanseri, DNA metilasyonu, DNA Metiltransferaz-3b, Metil Bağlayan Protein-1, miRNA, SNP.

SUMMARY: Aim: Lung cancer (LC) is a disease that develops by uncontrolled cell growth in tissues of the lung and the most common cause of cancer-related death. Most significant risk factors for LC are tobacco smoke, genetic factors, radon gas and asbestos.miRNAs bind target mRNAs which are complementary to their sequences and post-transcriptionally regulate gene expression through translational repression or mRNA degradation. Several observations link dysregulation of miRNA expression to the development and progression of tumors and miRNAs can act as oncogenes or tumor suppressors. The hypermethylation of CpG-dinucleotides in the promoter of genes and downregulation of tumor suppressors are important for tumorogenesis. It has been reported that being a type of epigenetic modifier, miRNAs, may regulate epigenetic mechanism including abnormal methylation of the promoter regions or histone modifications.For this purpose, we determined the SNPs on two miRNA genes targeting DNMT3b and MBD1 with current databases and aimed to investigate the association of these SNPs with lung cancer. Material and methods: Accordingly, 90-controls and 90-patients were included in our study (approval no: 2012/45). DNAs were isolated from blood samples and these DNA samples were genotyped by Sequenom MassARRAY System. The demographic characteristics of patients and types of genetic variation were evaluated by appropriate statistical methods. Results: It was determined that all individuals have the ancestral GG and AA genotype for rs72631831 variant of miR339 targeting DNMT3b and rs146020563 variant of miR15b targeting MBD1, respectively. 
Conclusion: We found no association between rs72631831 and rs146020563 variation with lung cancer, however our research is important due to being the first study to indicate the functional characterization of gene variants of miRNA genes targeting DNA methylation.

KEY WORDS: Lung cancer, DNA methylation, DNA methyltranferas-3b, Methyl Binding Protein-1, miRNA, SNP.

Giriş: Akciğer kanseri, kanserden ölüm nedenleri arasında ilk sirada olup, tüm kanser ölümlerinin yaklaşık üçte birini oluşturan ve akciğer doku hücrelerinin kontrolsüz çoğalmasıyla oluşan ölümcül bir hastalıktır $[1,2]$.

Etiyolojide en önemli faktörlerden biri sigaradır ve akciğer kanser gelişimine etkisinin yaklaşı $\% 85-90$ olduğu bilinmektedir. Akciğer kanseri riski sigara içenlerde içmeyenlere göre 30 kat fazladır. Ülkemizde akciğer kanserinin oluşumunda rol oynayan diğer bir faktör asbest temasıdır. Havayla taşınan, küçük partiküllere bölünen bir mineral bileşiği olan asbest özellikle sigara içenlerde, akciğer kanseri riskini artıran bir karsinojendir [1-3].

Akciğer kanserli bireylerin ailelerinde de akciğer kanseri ve diğer kanser tiplerinin izlenme sıklığı önemli düzeyde yüksek olup, ailesel geçiş ve genetik yatkınlık da hastalığın oluşmasında önemli rol oynar. Onkogenler veya tümör süpresör genlerde meydana gelen mutasyonlar, karsinojen metabolizmasındaki değişiklikler, hücre çoğalması, DNA replikasyonu veya onarımındaki bozukluklar genetik olarak kalıtılabilir ve kansere neden olabilir [1, 4].

Hücrelerin kanserleșme sürecinde önemli role sahip olan bu yolaklar "DNA dizi değişikliği olmadan mayotik ve/veya mitotik olarak kalıtılabilen gen ekspresyon değişiklikleri" ile yani epigenetik düzenlemeler ile de kontrol altındadır [5, 6]. Epigenetik mekanizmalar; DNA metilasyonu, histon modifikasyonları ve kodlamayan RNA'lar olarak sinıflandırılabilir $[5,7,8]$.
DNA metilasyonu en önemli epigenetik değişimlerden biri olup, genomda guaninden $(G)$ sonra gelen sitozinlerin $(C)$ metillenmesi ile oluşur. Genlerin promotör bölgelerinde bulunan sitozin ve guanin dinükleotidlerince zengin bölgelere $\mathrm{CpG}$ adacıkları ismi verilir ve $\mathrm{CpG}$ adaciklarında metilasyon az ise (hipometile) gen aktif yani açık, metilasyon çok ise (hipermetile) gen sessiz diğer bir ifadeyle kapalıdır [6, 9, 10]. DNA'nın metilasyonu, DNA metiltransferaz (DNMT) enzimleri tarafından katalizlenir ve metil bağlanma proteinleri (MBD1, MBD2, MBD3 vb) yardımıyla gerçekleşir $[6,11]$.

DNMT'ler metil vericisi olarak S-adenozil metionin'i kullanır ve sitozin 5-metiltransferaz olarak da adlandirılir. DNA metiltransferaz enziminin hedef bölgeleri $\mathrm{CpG}$ adacıklarıdır $[6,11]$. Günümüzde memelilerde 5 DNMT saptanmıştır: $\quad$ DNMT1, DNMT2, DNMT3a, DNMT3b ve DNMT3L $[5,10]$.

MBD ailesi proteinleri in vitro ve in vivo koşullarda metile DNA'yı seçici olarak tanıyıp bağlanan proteinlerdir. Metillenmiş $\mathrm{CpG}$ adalarına MBD proteinlerinin bağlanması histon deasetilaz gibi transkripsiyon baskılayıc1 proteinlerin bu komplekse katılmasina ve kapalı kromatin yapısının oluşmasına neden olur [12].

Gen ekspresyonu değişikliklerine bağl1 olarak DNA metiltransferaz ve MBD proteinlerin seviyelerinde meydana gelen değişiklikler akut miyeloid lösemide [13], akciğer [14, 15], göğüs [16, 17], kolorektal ve mide [18] kanserlerinin de içinde bulunduğu birçok kanser tipinde rapor edilmiştir. 
Transkripsiyon sonrası gen ekspresyonu kontrolünde yer alan en önemli moleküllerden biri de miRNA'lardır. miRNA'lar mRNAlarm 3' UTR bölgeleriyle baz eşleşmesi yapıp hedef mRNA yıkımını sağlayarak veya translasyona uğramalarını engelleyerek hedef gen ekspresyonunu azaltırlar [1922]. miRNA'lar dokuya özgü olarak eksprese olur ve hücre farklılaşması, çoğalması ve apoptozis gibi önemli hücresel yolakların düzenlenmesinde rol oynarlar [20, 22, 23].

miRNA ekspresyon değişiklikleri karsinogeneziste önemli role sahiptir. DNA metilasyonu veya histon modifikasyonları gibi epigenetik mekanizmaların bu düzenlenmeden etkilenebileceği ve miRNA ekspresyonunun DNA metilasyonunu direkt veya dolaylı olarak düzenleyebileceği belirtilmektedir [2426]. Paralel olarak son yillarda yapilan çalışmalarda, bazı mikroRNA'ların DNA metiltransferazlanı hedeflediği ve kanserdeki metilasyon değişiklikleri ile ilişkili oldukları belirlenmiştir [27]. Ayrıca miRNA dizilerindeki genetik varyasyonların (Single nucleotide polymorphism; SNP) miRNA ekspresyonunu veya olgunlaşmasını değiştirebileceği ve böylece kanser gelişimi ve ilerlemesine neden olabileceği belirtilmiştir [28].

Genetik polimorfizmler toplumda bulunma frekansı yüksek, bir gen veya DNA dizisindeki değișikliklerdir. DNA dizisindeki bu değişiklikleri mutasyondan ayıran özellik, en az 100 kişiden 1'nde bulunmasıdır. Genetik polimorfizmlerin en yaygın türü tek baz çifti varyasyonu içeren tek nükleotid polimorfizmleridir [29].

Tek nükleotid polimorfizmleri (SNP) genomda tek bir nükleotidin (A, T, C veya G) bir başkasıyla yer değiştirdiğinde oluşan DNA dizi değişimleridir [30].
Bazı gen polimorfizmleri bir hastalık riskini arttırırken bazıları azaltabilmekte (koruyucu alel), bazı polimorfik aleller ise yalnızca çevresel bir faktörün etkisi altındayken riski etkileyebilmektedir [31].

Araştırmamız kapsamında TargetScanHuman ${ }^{\circledR}$ veri bankası taramas1 yapılmış ve DNA metilasyonunda görevli DNMT3b ve MBD1'i hedefleyen 2 miRNA belirlenmiştir. $\mathrm{Bu}$ iki miRNA NCBI (National Center for Biotechnology Information)' 'n gen veri bankası taranmış ve 2 SNP araştırmaya dahil edilmiştir.

DNA metilasyonu ve miRNA gibi epigenetik kontrol mekanizmaları günümüz kanser araştırma çalışmalarında önemli bir yere sahip olmakla birlikte Ülkemiz'de ve Dünya'da global veya promotör DNA metilasyonunda görevli olan DNMT3b ve MBD1'i hedefleyen miRNA'lara ait genetik varyasyonların araştırıldığ 1 bir çalışma bulunmamaktadır. $\mathrm{Bu}$ amaçla biz de güncel veri tabanları ile DNMT3b ve MBD1'i hedefleyen 2 miRNA genine ait 2 SNP belirleyerek bu SNP'lerin akciğer kanseri ile ilişkisini araştırmayı amaçladık.

\section{Gereç ve Yöntemler:}

\section{Çalışma grubu bireyleri ve örneklerin toplanması}

Eskişehir Osmangazi Üniversitesi Tıp Fakültesi Gögüs Hastalıkları Anabilim Dalına başvuran 80 yaş altı 90 akciğer kanseri hastası ile 90 sağlıklı kontrol birey çalışmamıza dahil edilmiştir. Çalışmanın içeriğiyle ilgili olarak tüm hastalara detaylı bilgi verilerek hastalardan imzalı onam formu alınmıştır (Etik Kurul onay no: 2012/45) Her hastadan genetik varyasyon analizi için EDTA'lı tüpe $2 \mathrm{ml}$ venöz kan örneği alınmıştır. Çalışmamıza dahil edilen bireylerin demografik ve klinik özellikleri hakkındaki bilgiler kendilerinden ve kemoterapi hazırlık dosyalarından elde edilmiştir. 


\section{miRNA hedeflerinin ve miRNA genleri üzerinde yer alan SNP'lerin belirlenmesi}

Çalışmamızda DNA metilasyonunda görevli olan DNMT3b ve MBD1'i hedefleyen miRNA'lara ait genetik varyasyonların belirlenmesi planlanmıștır. Bunun için öncelikle http://mirdb.org/miRDB ve http://www.targetscan.org veri tabanları kullanılarak DNA metilasyonunda görevli DNMT3b ve MBD1 hedefleyen miRNA'lar tespit edilmiştir.

Belirlenen miRNA'lar NCBI Gene veri tabanında taranmış ve genetik varyasyona sahip miRNA genleri belirlenmiştir [32].

miRDB, TargetScanHuman ve NCBI veri tabanı taramaları sonucunda DNMT3b'yi hedefleyen miR339 genine ait rs72631831 ve MBD1'i hedefleyen miR15b geni üzerindeki rs146020563 varyasyonları çalışmaya dahil edilmiştir.

\section{DNA İzolasyonu ve miktarının belirlenmesi}

DNA izolasyonu için PureLink ${ }^{\mathrm{TM}}$ Genomic DNA Mini Kit (Invitrogen Corporation, Carlsbad, California, USA) kullanıldı.

Genotip analizlerin yapılacağı MassARRAY sistemi, fazla miktarda PCR amplikonlarına ihtiyaç duyduğu için kalıp genomik DNA'nın yüksek saflıkta olması gerekmektedir. $\mathrm{Bu}$ nedenle, Thermo Scientific NanoDrop ${ }^{\mathrm{TM}} \quad 1000$ spektrofotometrenin 260 ve $280 \mathrm{~nm}$ dalga boylarında ölçtüğü absorbans değerlerinin oranının $\left(\mathrm{A}_{260} / \mathrm{A}_{280}\right)$ 1,7 ile 2,0 arasında olması şartı arandı. Bu aralıktaki oran değerleri en düşük protein kontaminasyonunu göstermektedir (http://www.nanodrop.com/library/nd1000-v3.7-users-manual-8.5x11.pdf, 2710-2013).

\section{Genotip analizi}

Çalışmamızda belirlediğimiz miR339 ve miR15b geni üzerindeki rs72631831 ve rs146020563 varyasyonları Sequenom MassARRAY ${ }^{\circledR}$ System (Sequenom Inc., San Diego, California, ABD) üzerinde İplex GOLD SNP genotipleme kullanılarak analiz edildi.

MassARRAY genotipleme protokolü DNA amplifikasyonu, SAP (Shrimp Alkalen Fosfataz) reaksiyonu, İplex GOLD reaksiyonu, rezin ile temizleme ve MALDI-TOF analizi aşamalarından oluşmaktadır.

İplex GOLD genotiplemesinde ilk önce, hedeflenen SNP'ler için uygun amplifikasyon ve uzama primerlerinin dizaynı Sequenom Assay Designer v3.1 yazılımı ile yapıldı.

Primerlerin kütlelerini arttırmak için amplifikasyon primerlerinin 5' uçlarına bir 10-mer tag dizisi (5'-ACGTTGGATG3') eklendi. Böylelikle bu primerler MALDI-TOF kütle spektrometresinin tespit aralığı dışında kalması sağlandı. Varyasyon bölgelerinin amplifikasyonu için dizayn edilen ve üretici firmadan temin edilen primer çiftleri Tablo1'de gösterilmiştir.

Multipleks PCR reaksiyonu için DNA örnekleri 384 kuyucuklu PCR plakasına yüklendi. İplex GOLD reaksiyonu protokolüne göre multipleks PCR karıșımı hazırland $[(0.5 \mu \mathrm{M}$ Primer Mix, $25 \mathrm{mM}$ dNTP Mix (Applied Biosystems $\left.{ }^{\circledR}\right), 10 \mathrm{X}$ PCR Buffer (20 mM MgCl2 içeren) (Qiagen $\mathrm{GmbH}$ ), $5 \mathrm{U} / \mu$ l HotStarTaq DNA polimeraz (Qiagen $\mathrm{GmbH}$ ), $25 \mathrm{mM}$ $\mathrm{MgCl} 2$ (Qiagen $\mathrm{GmbH}$ ), Ultra saflaştırılmış su (Invitrogen ${ }^{\mathrm{TM}}$ )] ve hem örnek kuyucuklarına hem de DNA örneği içermeyen negatif kontrol kuyucuklarına yüklendi. Daha sonra, protokolde bildirilen şartlara göre termal cycler'da (Bio-Rad C1000 Thermal Cyler, 
California, USA) PCR reaksiyonu yürütüldü.

Varyasyon

bölgelerinin

amplifikasyonundan sonra İplex GOLD reaksiyonu ile varyasyonun tespit edilmesine yardımc olan uzama primerleri de dizayn edilerek üretici firmadan temin edildi (Tablo 1).

Amplifikasyondan sonra SAP karışımı [Ultra saflaştırılmış distile su (Invitrogen ${ }^{\mathrm{TM}}$ ), 10X SAP Buffer (Sequenom Inc.), $1.7 \mathrm{U} / \mu \mathrm{l}$ SAP Enzim (Sequenom Inc.)], PCR plakasındaki amplifikasyonu yapılmış kuyucukların üzerine dağıtıldı. Daha sonra PCR plakası, protokolde bildirilen şartlara göre termal cycler cihazında yürütüldü.

SAP reaksiyonundan sonra primer uzama reaksiyonu veya İplex GOLD reaksiyonu olarak adlandırılan PCR aşamasına geçildi.

$\mathrm{Bu}$ reaksiyona özel kütlesi modifiye edilmiş ddNTP karışımı kullanıldı (iPLEX Termination Mix). PCR karışımı [Ultra saflaştırılmış distile su (Invitrogen ${ }^{\mathrm{TM}}$ ), 10X İplexGOLD Buffer (Sequenom Inc.), İplex Termination mix (Sequenom Inc.), Primer karışımı, İplex enzim (Sequenom Inc.)], PCR plakaları üzerinde her örnek için ilgili konumdaki kuyucuğa yüklendi ve protokolde bildirilmiş PCR şartlarına göre plaka thermal cycler cihazında yürütüldü.

Primer uzama reaksiyonundan sonra uzamış ürünlerin kütle spektrometre analizini optimize etmek için rezin ile temizlik aşaması gerçekleştirildi. Katyonik rezin maddesinin kullanıldığ aşamada amaç; katyonik rezinin iyonlar ile yer değiştirme özelliğini kullanarak $\mathrm{Na}^{+}, \mathrm{K}^{+}$, ve $\mathrm{Mg}^{+2}$ iyonlarının ortadan kaldırılmasını sağlamaktır. MassARRAY sisteminin sunduğu bir düzenek sayesinde rezin (Sequenom Inc.) bütün kuyucuklara aktarıldı. Daha sonra, PCR plakasının döndürülerek oda sıcaklığında yaklaşık 35 dakika inkübasyonu yapıldı.

Rezin ile temizleme yapıld1ktan sonra ürünler Nanodispenser RS1000 cihazı ile SpectroCHIP'e aktarild1. SpectroCHIP üzerine aktarılan PCR ürünlerimizi kütlelerine göre analiz etmek için MALDI-TOF kütle spektrometre prensibi ile çalışan MassARRAY analizörü kullanıld1. Gerekli bilgiler girildikten sonra analiz işlemi başlatıldı. Böylelikle, analizör teker teker bütün kuyucukların matrikslerini lazer ile patlatarak içindeki PCR ürünlerinin kütlelerini analiz etmeye başladı. Kısa bir süre sonunda kütlelerine göre yaptığı analiz ile genotip sonuçlarının tamamını bilgisayar ekranında raporladi.

PCR ürünlerinin analizini MassARRAY kütle spektrometresinde gerçekleştirmek için, SpectroCHIP cihaza gerekli şekilde yerleştirilir. MassARRAY sistemi MALDI-TOF tekniğini kullanmaktadır. Sistem açıldıktan sonra, cihaza yerleştirilen çip üzerindeki matriks spotlar lazer sayesinde patlatılarak PCR ürünlerinin yüzey salınımı (desorpsiyon) ve iyonizasyonu gerçekleştirilir (MALDI). Lazer 1şın1, kütle spektrometresinde desorpsiyon ve iyonizasyon kaynağ 1 olarak görev yapar. Matriks, lazer ışınının enerjisini absorbe ederek ve PCR ürünlerinin desorpsiyonunu sağlayarak bu teknikte önemli bir rol oynamaktadır. Lazer ışını etkisiyle hızla dağılan matriks kümesi, vakum ortamına PCR ürünlerini taşıyarak iyonizasyon aşamasına destek olur. Ayrica, matriks molekülleri lazer enerjisinin tamamını absorbe ederek örnek zararını ve iyon fragmentasyonunu minimize etmektedir.

Uçurulan ve iyonize edilen örnek molekülleri elektrostatik olarak uçuş zamanlı bir kütle spektrometresi (TOFMS) tüpü içine aktarılır. Burada matriks iyonlarından ayrıştırılan örnekler, kütle/yük oranlarına $(\mathrm{m} / \mathrm{z})$ göre ayrı ayrı tespit edilerek analiz edilir. Teorik olarak 
sınırsız kütle aralığı ile birlikte yüksek iletim ve duyarlılık TOF cihazının kendine has avantajları arasındadır. Tüp sonundaki bir iyonun analizi, kütle/yük $(\mathrm{m} / \mathrm{z})$ oranının karekökü ile doğru orantılı olan uçuş zamanına dayanarak yapılmaktadir.

\section{İstatistiksel analiz}

Sürekli verilerin (süre, yıl, vb.) normal dağglıma uygunluğunun araştırılmasında Shapiro-Wilk testi kullanıldı. Normal dağılım göstermeyen sürekli değişkenlerin gruplar arası karşılaştırılması KruskalWallis analizi ile yapıldı.

Genotiplerin ve alellerin varlığı gibi kategorik yapıdaki değişkenlerin gruplar aras1 karşılaştırmalarında ki-kare analizleri kullanıldı. Genotiplerin gruplara göre ikili karşılaştırılmasında ise iki oran testi (Fisher's exact test) kullanıld1. ODDS oranları tek değişkenli ve çok değişkenli lojistik regresyon analizi ile hesapland.

Tüm analizler IBM SPSS Statistics 21 paket programı ile yapıldı. 0,05'den küçük olan $\mathrm{p}$ değeri anlamlı kabul edildi.

\section{Bulgular}

Çalışmamızda DNA metilasyonunda görevli olan DNMT3b ve MBD1'i hedefleyen miR339 ve miR15b geni üzerinde yer alan rs72631831 ve rs146020563 varyasyonlarının Türk toplumundaki sıklığını araştırmayı amaçladık.

Bireylerin cinsiyet, yaş, ak toprak maruziyeti ve sigara kullanımı gibi demografik özellikleri ile hastalık arasındaki ilişki karşılaştırıldığında çalışmamıza dahil edilen demografik veriler NSCLC ve SCLC için anlamlı bulundu $(\mathrm{p}<0,001)$ (Tablo 2).

Demografik verilerin akciğer kanser riski ile ilişkisi çoklu karşılaştırıldığında yaş ve sigara kullanımının hem NSCLC hem SCLC için anlamlı oranda riske sahip olduğu belirlendi $\quad(p<0,001)$. Kontrol bireylerde de aile hikayesine sahip bireylerin bulunmasi, ayrica kontrol grubunda hiçbir bireyin ak toprak maruziyeti bulunmaması nedeni ile bu iki veri bu teste dahil edilmedi. Çalışmamızda yer alan bireylerin demografik verileri çoklu karşılaştırıldığında, akciğer kanseri riski kadınlara göre erkeklerde 4.652 kat, sigara içmeyenlere göre sigara içenlerde 35.104 kat ve artan her bir yaşa göre 1.373 kat daha fazla bulundu (Tablo 3).

Bulgularımıza göre akciğer kanseri için en büyük risk olan sigara kullanımı değerlendirildiğinde sigara içme süresi ile hem NSCLC hem SCLC birey sayllar1 arasında anlamlı oranda fark bulundu $(\mathrm{p}<0,001)$ (Tablo 4).

Çalışmamızda araştırdığımız miR339 geni rs72631831 varyantı için hem kontrol $(n=90)$ hem de akciğer kanserli bireylerin tamamının $(n=90)$ atasal genotip olan GG genotipine sahip olduğu tespit edildi (Tablo 5). rs72631831 varyantı için değişken bulunmaması nedeni ile istatistiksel değerlendirme yapılmadı.

Benzer şekilde araştırdığımı diğer varyant olan miR15b geni rs 146020563 varyantı için de hem kontrol $(n=90)$ hem de akciğer kanserli bireylerin tamamı $(n=90)$ atasal genotip olan AA genotipine sahip olarak belirlendi (Tablo 5). rs146020563 varyantı için değişken bulunmaması nedeni ile istatistiksel değerlendirme yapılmadi.

\section{Tartışma}

\section{Demografik Değerlendirilmesi}

Özelliklerin

Birçok kanser türünde olduğu gibi akciğer kanserinin de oluşumunda birçok faktör etkendir. Yaş, cinsiyet, kimyasal karsinojenlere maruziyet ve aile hikayesi kanser etyolojisinde önemli yere sahiptir [33]. 
Yapılan risk analiz çalışmalarında, sigaranın hastalığın oluşumu için en önemli risk faktörlerinden biri olduğu, sigara kullanım miktarı ve süresinin bu risk ile yakından ilişkili olduğu belirlenmiştir. Sigaraya bağlı hasarın ortaya çıkması ortalama 20 yıl sürmekte bu nedenle hastalık 50 yaş ve sonrasında ortaya çıkmaktadır [33, 34]. Benzer şekilde bizim çalışma grubumuzda yapılan çoklu risk analizinde artan her bir yaş için 1.373 kat ve sigara içmeyenlere göre içenlerde 35.104 kat daha fazla risk olduğu belirlenmiştir. Cinsiyetin akciğer kanser riski üzerine etkileri tartışmalıdır. Kimyasal karsinojenlere maruz kalma durumu erkeklerde daha fazla olduğu için akciğer kanseri riskinin erkeklerde kadınlara göre daha fazla olduğu ama bu farkın istatistiksel olarak anlamlı olmayabileceği belirtilmiştir [33]. Benzer şekilde bizim çalışmamızdaki çoklu karşılaştırmada erkek bireylerde kadınlara göre 4.652 kat risk belirlenmiş, ancak sigara ve yaş faktörleri ile birlikte değerlendirildiğinde istatistiksel anlam bulunmamıștır.

Akciğer kanser gelişiminde rol oynayan mesleki karsinojenlerden en önemlisi asbesttir. Asbest ve arsenik, silika ve radon gibi mesleki karsinojenlere maruz kalma akciğer kanseri riskini artırırken aynı zamanda sigara içen bireylerde risk 50 kata kadar artabilir $[35,36]$. Ak toprak olarak da bilinen asbeste Ülkemizde yalnızca mesleki olarak değil coğrafi olarak maruziyet profili oluşturmaktır. Özellikle Eskişehir, Kütahya ve çevresinde izolasyon malzemesi olarak kullanılan asbest bu bölgelerde akciğer kanseri gelişimi için önemli bir risk unsurudur [3]. Bizim çalışmamızda yer alan akciğer kanserli bireylerin \% 46, 6 'sinda asbest maruziyeti bulunmaktadir. $\mathrm{Bu}$ nedenle çalıştığımız popülasyon için asbest maruziyeti de önemli bir risk faktörü olarak belirlenmiştir.
Akciğer kanseri veya kanser öyküsünün de akciğer kanseri için anlamlı bir risk unsuru olduğu belirtilmektedir. Özellikle birinci derece akrabalarında akciğer kanseri hastalığı bulunan ve sigara kullanan bireylerde bu risk artmaktadır [33]. Benzer şekilde çalışmamızda yer alan 180 bireyin 81 'inde $(\% 45)$ ve 90 akciğer kanserli bireyin 46'sında (\% 51,1) birinci derece akrabalarda akciğer kanseri öyküsü bulunmaktadır. Çalıştığımız popülasyon için aile öyküsünün de önemli risk faktörlerinden biri olduğu belirlenmiştir.

\section{Genetik Değerlendirilmesi}

Varyasyonların

DNMT3b, memeli genomunda yer alan DNA metiltransferaz enzimlerinden biri olup, hem yarı metillenmiş DNA metillenmesinde hem de de novo metilasyonda görev alır [6, 10]. Bilindiği gibi hücre döngüsünün düzenlenmesinde, DNA tamiri ve apoptozda görev alan tümör süpresör genlerin epigenetik olarak sessizleşmesine neden olan bozulmuş DNA metilasyonu karsinogenezde önemli role sahiptir [37]. Yapılan çalışmalarda DNMT3b'nin, akciğer kanseri [38], skuamöz hücreli baş ve boyun kanseri [39], göğüs kanseri [40], özefagal ve gastrik kanser [37] gibi birçok kanser tipi ile ilişkili olduğu ve özellikle aşırı ekspresyonunun karsinogeneze önemli etkisi olduğu belirlenmiştir [37].

Janssen ve arkadaşları DNMT3b'yi hedefleyen miR1274a'nın göğüs kanserinde proliferasyon ile ilişkili olduğunu belirlemişlerdir [41].

DNMT3b'yi hedefleyen bir diğer miRNA miR26b'dir ve yapılan çalışmalarda miR26b'nin hepatoselüler karsinom, nazofarengial karsinom, primer skuamöz hücreli akciğer karsinomu ve gögüs kanseri gibi birçok kanser türünde downregüle olduğu, MCF-7 göğüs kanseri hücre dizilerinde ise aşırı ekspresse olduğu rapor edilmiştir [42]. Agresif 
özellik gösteren glioma hücrelerine miR26b transfeksiyonu yapıldığında glioma gelişiminde azalma belirlenmiş olup, bu hücreler için artmış ekspresyonun anti-tümör etkiye sahip olabileceği belirtilmiştir [43].

Çalıșmamızda rs72631831 varyantını araştırdığımız miR339, DNMTb'yi hedefleyen bir başka miRNA olup, 7. kromozom üzerinden kodlanan bir miRNA'dır. Zhou ve arkadaşları miR339'un kolorektal kanser hücrelerinde büyümeyi ve metastazı inhibe ederek tümör süpresör aktivite gösterdiğini belirlemiştir [44].

$\mathrm{Wu}$ ve arkadaşları miR339 ekspresyonunun agresif hücre hatlarında ve göğüs kanseri hücrelerinde downregüle olduğunu ve miR339 transfeksiyonunun kanser hücre büyümesini, tümör hücresi göçünü ve invazyon kapasitesini azalttığını belirlemişlerdir [45].

rs72631831 numaralı genetik varyantlarını araştırdığımız miR339 geni tüm hasta ve kontrol bireylerde atasal genotipe sahip olarak belirlenmiştir. Literatürde veriye rastlanmayan rs72631831 ile akciğer kanseri arasında bir ilișki bulunamamıș olup, bu bölgelenin oldukça korunmuş bir bölge olabileceği düşünülmektedir.

MBD1 diğer metil-CpG-DNA'ya bağlanan proteinler gibi memeli nüklear proteinlerinin önemli üyeleridir. MBD1, p16 ve E-kaderin genleri gibi tümör süpresörlerin metile $\mathrm{CpG}$ adacıklarına bağlanarak transkripsiyonu düzenler. MBD2'nin ise DNA demetilaz aktivitesi ile represör özellik gösterdiği belirlenmiştir [46]. Bader ve arkadaşları MBD1 ve 2 geni üzerindeki mutasyonların veya ekspresyon değișikliklerinin kolon ve akciğer kanseri ile ilişkili olabileceğini bildirmişlerdir [47].

Jiang ve arkadaşları NSCLC dokularda MBD1'i hedefleyen bir miRNA olan
miR125a'nın ekspresyonunun normal dokulara göre azalmış olduğunu ve miR125a ekspresyonunun akciğer kanseri hücrelerinde invazyon ve metastazı azaltabileceğini rapor etmişlerdir [48]. Benzer şekilde miR125a'nın akciğer kanseri hücrelerinde p53'ü aktive ederek apoptozu indüklediği belirlenmiştir [49].

$\begin{array}{lcc}\text { Çalışmamızda } & \text { rs146020563 } & \text { varyantını } \\ \text { araştırdığımız miR15b } & \text { MBD1'i } \\ \text { hedefleyen miRNA'lardan biri olup, 3. } & \text { olum, } \\ \text { kromozom üzerinden } & \text { kodlanır } \\ \text { (http://www.ncbi.nlm.nih.gov/gene/, }\end{array}$
http://www.targetscan.org). Xia ve arkadaşları miR15b'nin hücre döngüsü için önemli role sahip olduğunu ve aşırı eksprese olduğunda hücre döngüsünün G0/G1 fazında durduğunu belirlemişlerdir [50]. Benzer şekilde Chung ve arkadaşları hepatoselüler karsinomada miR15b transfeksiyonun azalmış proliferasyon ve artmış apoptoz ile ilişkili olduğunu bildirmiştir [51].

Çalışmamızda miR15b geni üzerindeki rs146020563 varyasyonu araştırılmış olup, tüm bireyler atasal genotip olarak belirlenmiştir. Bu varyant için de literatür bilgisi bulunmamakla birlikte rs146020563 ve varyantı akciğer kanseri ile ilişkili bulunmamıştır.

\section{Sonuç}

Akciğer kanseri tüm dünyada ve Ülkemizde sıklıkla aile öyküsünün eşlik ettiği sigara dumanı ve asbest maruziyeti sonucu oluşan kötü prognozlu, düşük sağ kalımlı ve ölümcül bir hastalıktır. Akciğer kanseri ve karsinogenezle ilgili araştırmalara her gün bir yenisi eklenmekte olup, hastalığın moleküler nedenlerinin belirlenmesi ve yeni geliştirilen terapilerin hedeflenmesi günümüz kanser araştırmalarının ana hedefidir.

Biz de araştırmamızda karsinogenezde önemli role sahip olan, DNA metilasyonunda görevli DNMT3b ve 
MBD1'i, yine epigenetik olarak kontrol eden miRNA'ların gen varyasyonları ile akciğger kanseri arasındaki ilişkiyi ve bu varyasyonların Türk toplumundaki sıklığını araştırmayı amaçladık.

Araştırmamızda genotiplendirdiğimiz iki varyant hem kontrol hem de akciğer kanserli bireylerde atasal genotipte belirlenmiş olup, oldukça korunmuş bölgeler olarak belirlediğimiz bu varyantların akciğer kanseri ile ilişkisi bulunmamıştır. Ancak bu varyantlar ilk kez fonksiyonel karakterizasyonu yapilan SNP'ler olup, hem veri bankaları hem araştırmacılar için özgün veri niteliğinde olacaktır.

\section{KAYNAKLAR}

1. Aydıner, A. (2007). Akciğer kanseri: 9. Lüleyap, Ü.H. (2008). Moleküler tan1-tedavi-takip.(Nobel Tip Kitabevleri). genetiğin esasları. (Ankara: Nobel Tip Kitabevleri).

2. Ak, G. and Metintaş, M. (2014). 10. Çelik, S. (2007). Kronik miyeloid Akciğer kanseri, tanı ve destek tedavisinde aile hekimi.(Ankara: Rotatıp Kitabevi).

3. Metintaş, M. (2005). Asbest temasına bağlı plevral patolojiler ve mezotelyoma. Turkiye Klinikleri Journal of Internal Medical Sciences 1, 96-110.

4. Topu, Z. Ülger, F. and Numanoğlu, N. (2004). Ailesel kanser hikayesi ve akciğer kanseri. Tüberküloz ve Toraks Dergisi. 52,130-136.

5. Onay, H. (2006). Konvansiyonel renal hücreli kanser oluşumunda etkili olan genlerin metilasyon durumunun araştırılmasi. Doktora Tezi, Ege Üniversitesi İzmir.

lösemili hastalarda dap kinaz geninin metilasyon analizleri. Yüksek Lisans Tezi, Ankara Üniversitesi, Biyoteknoloji Enstitüsü, Ankara.

11. Varol, N. (2007). Akut Lösemilerde Socs-1 Geninin Metilasyon Analizi. Yüksek Lisans Tezi, Ankara Üniversitesi, Sağlık Bilimleri Enstitüsü Ankara.

12. Kaymak, A. (2012). Farklı kanserlerin hücre hatlarında demetilasyon oluşturulması ile tümör süpresör ve stamp ailesi gen ifade değişikliklerinin incelenmesi. Yüksek Lisans Tezi, Ege Üniversitesi Sağlık Bilimleri Enstitüsü, İzmir.

13. Garzon, R. Liu, S. Fabbri, M. Liu, Z. Heaphy, C.E. Callegari, E. Schwind, S. Pang, J.Yu, J. and Muthusamy, N. (2009). MicroRNA-29b induces global DNA hypomethylation and tumor suppressor gene reexpression in acute myeloid leukemia by targeting directly DNMT3A and 3B and indirectly DNMT1. Blood 113, 6411-6418. ar1. Hacettepe Tip Dergisi. $38,48-54$.

4. Tang, M. Xu, W. Wang, Q. Xiao, W. and $\mathrm{Xu}, \mathrm{R}$. (2009). Potential of DNMT and its epigenetic regulation for lung cancer therapy. Current Genomics. 10, 336.

phenomena. Current Issues in Molecular Biology 4, 111-128.

15. Belinsky, S.A. Klinge, D.M. Stidley, C.A. Issa, J.P. Herman, J.G. March, 
T.H. and Baylin, S.B. (2003). Inhibition of DNA methylation and histone deacetylation prevents murine lung cancer. Cancer Research. 63, 7089-7093.

16. Lin, X. and Nelson, W.G. (2003). Methyl-CpG-binding domain protein-2 mediates transcriptional repression associated with hypermethylated GSTP1 CpG islands in MCF-7 breast cancer cells.

Cancer Research. 63, 498-504.

17. Ballestar, E. Paz, M.F. Valle, L. Wei, S. Fraga, M.F. Espada, J. Cigudosa, J.C. Huang, T.H.M. and Esteller, M. (2003). Methyl-CpG binding proteins identify novel sites of epigenetic inactivation in human cancer. The EMBO Journal. 22, 6335-6345.

18. Kanai, Y. Ushijima, S. Kondo, Y. Nakanishi, Y. and Hirohashi, S. (2001). DNA methyltransferase expression and DNA methylation of CPG islands and peri-centromeric satellite regions in human colorectal and stomach cancers. International Journal of Cancer. 91, 205-212.

19. Bandres, E. Agirre, X. Bitarte, N. Ramirez, N. Zarate, R. Roman-Gomez, J. Prosper, F. and Garcia-Foncillas, J. (2009). Epigenetic regulation of microRNA expression in colorectal cancer. International Journal of Cancer. 125, 2737-2743.

20. Lehmann, U. Hasemeier, B. Christgen, M. Muller, M. Romermann, D. Langer, F. and Kreipe, H. (2008). Epigenetic inactivation of microRNA gene hsamir-9-1 in human breast cancer. $J$ Pathol.214, 17-24.

21. Lujambio, A. Ropero, S. Ballestar, E. Fraga, M.F. Cerrato, C. Setién, F. Casado, S. Suarez-Gauthier, A. Sanchez-Cespedes, M. and Gitt, A. (2007). Genetic unmasking of an epigenetically silenced microRNA in human cancer cells. Cancer Research. 67, 1424-1429.

22. Saito, Y. Liang, G. Egger, G. Friedman, J.M. Chuang, J.C. Coetzee,
G.A. and Jones, P.A. (2006). Specific activation of microRNA-127 with downregulation of the proto-oncogene BCL6 by chromatin-modifying drugs in human cancer cells. Cancer Cell. 9, 435-443.

23. Saydam, F. Değirmenci, İ. and Güneş, H.V. (2011). MikroRNA'lar ve kanser Dicle Tip Dergisi. 38, 113-120.

24. Han, L. Witmer, P.D.W. Casey, E. Valle, D. and Sukumar, S. (2007). DNA methylation regulates MicroRNA expression. Cancer Biology and Therapy 6, 1284.

25. Iorio, M.V. Piovan, C. and Croce, C.M. (2010). Interplay between microRNAs and the epigenetic machinery: an intricate network. Biochimica et Biophysica Acta (BBA)-Gene Regulatory Mechanisms 1799, 694701.

26. Weber, B. Stresemann, C. Brueckner, B. and Lyko, F. (2007). Methylation of human microRNA genes in normal and neoplastic cells. Cell Cycle-Landes Bioscience. 6, 1001.

27. Fabbri, M. Garzon, R. Cimmino, A. Liu, Z. Zanesi, N. Callegari, E. Liu, S. Alder, H. Costinean, S. and FernandezCymering, C. (2007). MicroRNA-29 family reverts aberrant methylation in lung cancer by targeting DNA methyltransferases $3 \mathrm{~A}$ and $3 \mathrm{~B}$. Proceedings of the National Academy of Sciences.104, 15805-15810.

28. Kim, M.J. Yoo, S.S. Choi, Y.Y. and Park, J.Y. (2010). A functional polymorphism in the pre-microRNA$196 \mathrm{a} 2$ and the risk of lung cancer in a Korean population. Lung Cancer. 69, 127-129.

29. Shenfield, G.M. (2004). Genetic polymorphisms, drug metabolism and drug concentrations. The Clinical BiochemistReviews/Australian Association of Clinical Biochemists.25, 203-206.

30. Vignal, A. Milan, D. SanCristobal, M. and Eggen, A. (2002). A review on SNP and other types of molecular markers and their use in animal 
genetics.Genetics Selection, evolution : GSE 34, 275-305.

31. Ekmekçi, A. Konaç, E. and Önen, H.İ. (2008). Gen polimorfizmi ve kansere yatkınlık. Gen. 21, 282-295.

32. http://www.ncbi.nlm.nih.gov/gene/

33. Spitz, M.R. Hong, W.K. Amos, C.I. Wu, X. Schabath, M.B. Dong, Q. Shete, S. and Etzel, C.J. (2007). A Risk Model for Prediction of Lung Cancer. Journal of the National Cancer Institute. 99, 715-726.

34. Tammemagi, C.M. Pinsky, P.F. Caporaso, N.E. Kvale, P.A. Hocking, W.G. Church, T.R. Riley, T.L. Commins, J. Oken, M.M. and Berg, C.D. (2011). Lung cancer risk prediction: prostate, lung, colorectal and ovarian cancer screening trial models and validation. Journal of The National Cancer Institute. 103, 10581068.

35. Karlıkaya, C. Öztuna, F. Solak, Z.A. Özkan, M. and Örsel, O. (2006). Tütün kontrolü. Toraks Dergisi. 7:51-64.

36. Frost, G. Darnton, A. and Harding, A.H. (2011). The Effect of Smoking on the Risk of Lung Cancer Mortality for Asbestos Workers in Great Britain (1971-2005). Annals of Occupational Hygiene 55, 239-247.

37. Chen, M.F. Lu, M.S. Lin, P.Y. Chen, P.T. Chen, W.C. and Lee, K.D. (2012). The role of DNA methyltransferase $3 b$ in esophageal squamous cell carcinoma. Cancer.118, 4074-4089.

38. Shen, H. Wang, L. Spitz, M.R. Hong, W.K. Mao, L. and Wei, Q. (2002). A novel polymorphism in human cytosine DNA-methyltransferase-3B promoter is associated with an increased risk of lung cancer. Cancer Research.62, 4992-4995.

39. Liu, Z. Wang, L. Wang, L.E. Sturgis, E.M. and Wei, Q. (2008). Polymorphisms of the $<$ i> DNMT3B $</ \mathrm{i}>$ gene and risk of squamous cell carcinoma of the head and neck: A case-control study.Cancer Letters. 268, 158-165.
40. Sandhu, R. Rivenbark, A.G. and Coleman, W.B. (2012). Enhancement of chemo-therapeutic efficacy in hypermethylator breast cancer cells through targeted and pharmacologic inhibition of DNMT3b. Breast Cancer Research and Treatment. 131, 385-399.

41. Janssen, E.A. Slewa, A. Gudlaugsson, E. Jonsdottir, K. Skaland, I. Søiland, H. and Baak, J.P. (2010). Biologic profiling of lymph node negative breast cancers by means of microRNA expression. Modern Pathology. 23, 1567-1576.

42. Li, J. Kong, X. Zhang, J. Luo, Q. Li, X. and Fang, L. (2013). MiRNA-26b inhibits proliferation by targeting PTGS2 in breast cancer. Cancer Cell Int.13.

43. Wu, N. Zhao, X. Liu, M. Liu, H. Yao, W. Zhang, Y. Cao, S. and Lin, X. (2011). Role of microRNA-26b in glioma development and its mediated regulation on EphA2. PLoS One 6. e16264.

44. Zhou, C. Liu, G. Wang, L. Lu, Y. Yuan, L. Zheng, L. Chen, F. Peng, F. and Li, X. (2013). MiR-339-5p regulates the growth, colony formation and metastasis of colorectal cancer cells by targeting PRL-1. PloS one 8 . e63142.

45. Wu, Z.S. Wu, Q. Wang, C.Q. Wang, X.N. Wang, Y. Zhao, J.J. Mao, S.S. Zhang, G.H. Zhang, N. and Xu, X.C. (2010). MiR-339-5p inhibits breast cancer cell migration and invasion in vitro and may be a potential biomarker for breast cancer prognosis. $B M C$ Cancer.10, 542.

46. Patra, S.K. Patra, A. Zhao, H. Carroll, P. and Dahiya, R. (2003). Methyl$\mathrm{CpG}-\mathrm{DNA}$ binding proteins in human prostate cancer: expression of CXXC sequence containing MBD1 and repression of MBD2 and $\mathrm{MeCP} 2$. Biochemical and biophysical research communications 302, 759-766.

47. Bader, S. Walker, M. McQueen, H.A. Sellar, R. Oei, E. Wopereis, S. Zhu, Y. 
Peter, A. Bird, A.P. and Harrison, D.J. (2003). MBD1, MBD2 and CGBP genes at chromosome 18q21 are infrequently mutated in human colon and lung cancers. Oncogene. 22, 35063510 .

48. Jiang, L. Huang, Q. Zhang, S. Zhang, Q. Chang, J. Qiu, X. and Wang, E. (2010). Hsa-miR-125a-3p and hsamiR-125a-5p are downregulated in non-small cell lung cancer and have inverse effects on invasion and migration of lung cancer cells. $B M C$ Cancer. 10, 318.

49. Jiang, L. Chang, J. Zhang, Q. Sun, L. and Qiu, X. (2013). MicroRNA HsamiR-125a-3p Activates p53 and induces apoptosis in lung cancer cells. Cancer Investigation. 31, 538-544.

50. Xia, H. Qi, Y. Ng, S.S. Chen, X. Chen, S. Fang, M. Li, D. Zhao, Y. Ge, R. and Li, G. (2009). MicroRNA-15b regulates cell cycle progression by targeting cyclins in glioma cells. Biochemical and biophysical research communications 380, 205-210.

51. Chung, G.E. Yoon, J.H. Myung, S.J. Lee, J.H. Lee, S.H. Lee, S.M. Kim, S.J. Hwang, S.Y. Lee, H.S. and Kim, C.Y. (2010). High expression of microRNA$15 \mathrm{~b}$ predicts a low risk of tumor recurrence following curative resection of hepatocellular carcinoma. Oncology Reports. 23, 113-119. 